\title{
Unexpected biodiversity loss under global warming in the neotropical Guayana Highlands: a preliminary appraisal
}

\author{
VALENTÍ RULL* and TERESA VEGAS-VILARRÚBIA † \\ *Departament de Biologia Animal, Biologia Vegetal i Ecologia, Universitat Autònoma de Barcelona 08193 Bellaterra, \\ Barcelona, Spain, †Departament d’Ecologia, Universitat de Barcelona, Av Diagonal 645, 08028 Barcelona, Spain
}

\begin{abstract}
The fully vegetated summits of the table mountains that form the Guayana Highlands (GH), in northern South America, hold amazing biodiversity and endemism levels, and unique vegetation types. In spite of their present-day healthy appearance, their biota is seriously threatened of habitat loss by upward displacement, because of the projected warming for the end of this century. Available data are still insufficient for a definite assessment, but preliminary estimations based on representative endemic vascular plant species show that roughly one-tenth to one-third of them would loss their habitat with the $2-4{ }^{\circ} \mathrm{C}$ temperature increase predicted for the region by AD 2100 . Given the underlying endemism, the eventual loss of biodiversity will be of global nature. Other mountain ranges around the world with similar characteristics of the $\mathrm{GH}$, namely topographical isolation, high endemism and absence of nival stage because of the lower altitude, would be under similar unexpected risk, and should be urgently considered for conservation purposes.
\end{abstract}

Keywords: biodiversity, conservation, endemism, extinction, global warming, Guayana, habitat loss, high mountains, migration, tropics

Received March 7, 2005; revised version received and accepted October 5, 2005

\section{Introduction}

Among the predicted consequences of global change, there is a generalized biodiversity loss, which could be especially significant in high-latitude and high-mountain biomes (McCarthy et al., 2001; Chapin et al., 2004). On high-mountain biomes, the main reason is the displacement of environmental conditions to higher altitudes because of global warming, and the consequent community fragmentation and/or habitat loss for taxa living on climatically extreme environments above the treeline (Dirnböck et al., 2003; Körner, 2004; and literature therein). Upland biotic migrations and corresponding community reorganizations following the recent warming trend started at the beginning of the industrial era (ca. AD 1750) have been already documented, in temperate mountains (Grabherr et al., 1994; Pauli et al., 1996; Keller et al., 2000; Dullinger et al., 2003; Parmesan \& Yohe, 2003; Root et al., 2003). Tropical mountains,

Correspondence: Valentí Rull, fax +34 93 5811321,

e-mail: valenti.rull@uab.es however, have been largely ignored in this respect. In general, it is believed that the tropics are prone of suffering intensified aridity episodes or catastrophic events (cyclones, floodings, etc.), rather than habitat loss, as a consequence of climatic change (McCarthy et al., 2001). In particular, tropical mountain biotas are believed to be more threatened by changes in land-use intensity (Molau, 2004). However, upward migration has been recognized as a crucial biogeographical factor in tropical mountains, in relation to past and future climate changes (Bush, 2002). Here, the case of the neotropical Guayana Highlands (GH) is analysed to illustrate the potentially severe consequences of the predicted 21st century warming on highland biotas from tropical mountains, even on those of low/medium altitude, with no permanent snow and fully vegetated summits, presently under favourable mild and wet climates. This is still a preliminary overlook, because of the lack of data detailed enough for a more definite assessment. The main aim is to make evident the potential and unexpected danger for these and other similar tropical mountain areas, in order to promote 
more detailed studies hopefully leading to suitable conservation strategies.

\section{The GH}

The GH, situated between the Amazon and the Orinoco basins (Fig. 1), are the assemblage of the more or less flat tops of remote and spectacular table mountains, the tepuis, which form the discontinuous Pantepui biogeographical province, of about $5000 \mathrm{~km}^{2}$ and $1500-3000 \mathrm{~m}$ elevation (Huber, 1994). In the present context, the terms GH and Pantepui are roughly equivalent and will be used with the same physiographical meaning. The tepuis have been developed by long-term erosion of the Precambrian sandstone/quartzites of the Roraima Formation, which are part of the Guayana Shield (Briceño \& Schubert, 1990). More than 100 of these mountains are known, most in Venezuela, albeit few lie on Brazil, Colombia and Guyana (Steyermark, 1986). The more common altitude of the tepui summits is between 2000 and $2600 \mathrm{~m}$, with a maximum of $3014 \mathrm{~m}$ at Sierra de la Neblina, in the border between Venezuela and Brazil (Berry et al., 1995). The GH climate is mild and perhumid. Mean annual temperature is between $12^{\circ} \mathrm{C}$ and $18^{\circ} \mathrm{C}$ with negligible seasonal oscillations, and total annual rainfall averages $2500-3500 \mathrm{~mm}$, without dry season (Berry et al., 1995).

On the tepui summits, biodiversity and endemism are among the world's largest as shown, for example, by vascular plant records, by far the better known Pantepui organisms. Although the flora is still not entirely known, 2322 species of vascular plants have been found in these densely vegetated summits, of which $766(33.0 \%)$ are endemic to the $\mathrm{GH}$, and 1517 (65.3\%) are endemic to the Guayana Shield (Berry et al., 1995). Local endemism, i.e. the restriction to one single tepui summit, is outstanding, reaching over $60 \%$ in some tepuis (Steyermark, 1986). At supraspecific level, the endemism is also remarkable, including 23 genera and the family Tepuianthaceae (Berry et al., 1995). The origin of such degree of biodiversity and endemism is still controversial. Earlier workers proposed that the GH flora evolved in topographical isolation because of the formation of the tepuis in the late Cretaceous, and vicariance has been the main diversification mechanism (Maguire, 1970). Others, however, believe that biotic connection among tepuis has been possible during the Quaternary glacial cycles by vertical migration, and invoke ecological factors, for example, the spatial distribution of particular edaphic conditions, to explain endemism patterns (Steyermark \& Dunsterville, 1980; Huber, 1988; Berry et al., 1995). It has also been proposed that Pantepui would have been a biotic refuge during the glaciations, thus, contributing to the genera-
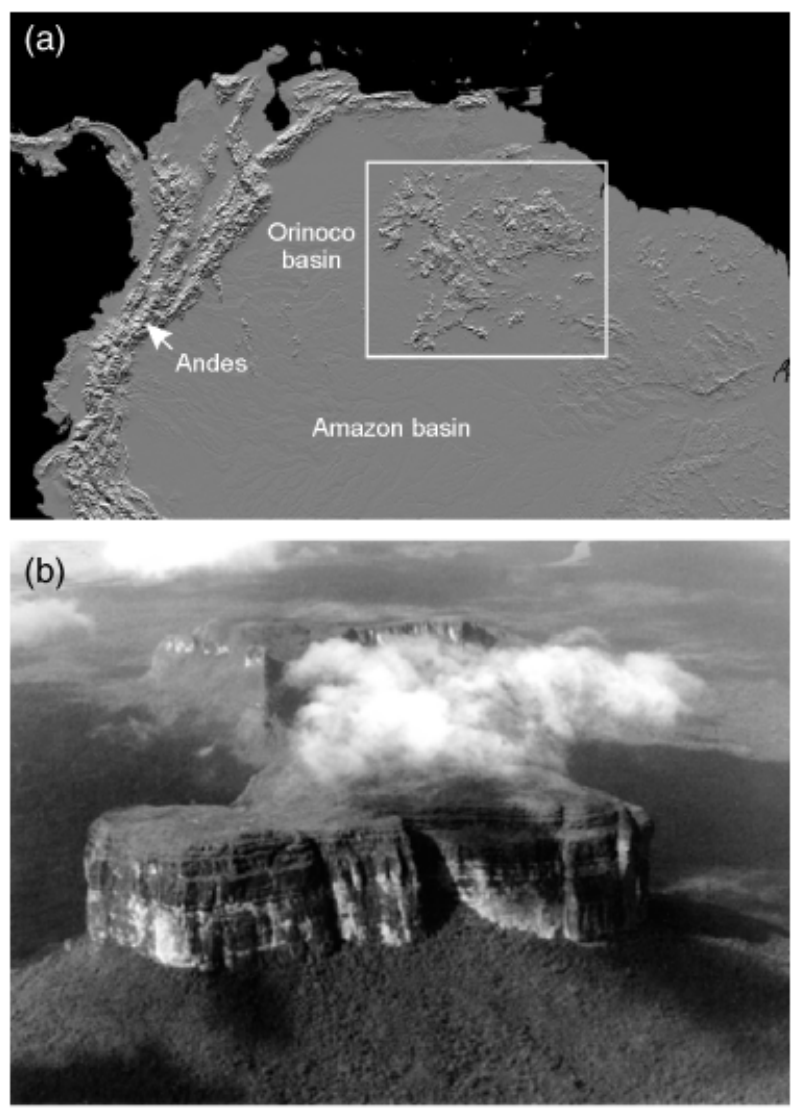

Fig. 1 Location map and typical Guayana Highlands (GH) landscape. (a) Radar image of northern South America showing the location of the GH (rectangle), in relation to the Orinoco and Amazon basins, and the northern Andean range (source image courtesy of NASA/JPL-Caltech). (b) Aerial view of the tepui Cerro Venado (photo by V. Rull).

tion of new endemic species, also by geographical isolation and allopatric speciation (Steyermark, 1979, 1986). But the refuge hypothesis has been severely criticized in the $\mathrm{GH}$, on the basis of palaeoecological evidence (Rull, 2004c). Recently, Rull (2005b) proposed a diversification model linked to glacial-interglacial alternation, without reference to the refuge hypothesis, which involves gene flow among the tepuis - because of the vertical biotic migration - and the interaction of several speciation mechanisms in addition to vicariance.

The GH vegetation is dense and luxuriant, and includes four main categories: forests, shrublands, meadows and pioneer formations. Some peculiar formations belonging to these types are unique and characteristic of the tepui summits. Among forests, the more emblematic and well known are the high-tepui Bonnetia forests (Fig. 2), dominated by trees of this Theaceae genus. They grow mostly on peats and mineral soils derived 
from diabase intrusions, typically between 1700 and $2600 \mathrm{~m}$, along water courses (gallery forests) and in wet depressions. Physiognomically, the Bonnetia forests are low $(6-12 \mathrm{~m})$ and with a dense and homogeneous canopy formed by a few species, mainly $B$. roraimae, $B$. tepuiensis and B. wurdackii (Berry et al., 1995). Shrublands are especially well developed in Pantepui, both physiognomically and floristically. Most of them grow on rock outcrops, sandy soils or peat. A singular shrubland type that occurs only in the $\mathrm{GH}$ is the paramoid scrub, characteristic of the huge Chimantá massif ( $>600 \mathrm{~km}^{2}$ of summit area), where it is restricted (Huber, 1992). These scrubs are organized around 3 species of the endemic Asteraceae genus Chimantaea (C. mirabilis, C. humilis and C. lanocaulis), with characteristic stem rosettes (caulirossulae) 1-3 m tall, develop dense and extensive colonies on organic water-saturated soils (Fig. 2). The paramoid shrublands grow on the highest summits of the Chimantá massif up to around $2600 \mathrm{~m}$, showing a notable diversification and geographical segregation (Huber, 1992). The name of this formation comes from its remarkable physiographical and taxonomic resemblance with the Andean páramos, dominated by caulirossulae of Espeletia (Asteraceae), situated above the treeline (Luteyn, 1999). The tepui meadows are herbaceous vegetation types dominated by herbs without a gramineous morphology, mainly Rapateaceae and Xyridaceae. In the GH, the dense broad-leaved meadows are typical, especially those dominated by Stegolepis (Rapateaceae), which is the prevailing and most characteristic floristic element of this biome in the Guayana region (Fig. 2), with a conspicuous geographical and altitudinal differentiation (Huber, 1988; Berry et al., 1995). These formations grow on deep and wet organic soils, attaining up to $\sim 1 \mathrm{~m}$ tall, and are spiked by small stands of shrubs, mainly of Asteraceae, Cyrillaceae and Rubiaceae. Finally, pioneer formations (lithobiomes) are early colonizers of bare habitats, mostly exposed rock surfaces. There are not vascular plants, but cyanobacteria, fungi and incrustant lichens, which contribute to rock weathering. On incipient organic soils, more advanced successional stages are represented by small clusters of vascular plants also present in shrublands and meadows, mainly Bromeliaceae, Ericaceae, Xyridaceae and Rapateaceae (Berry et al., 1995).

The Pantepui region is still nearly pristine. International conservation organizations have recognized the GH as a preferential subject for biodiversity preservation. They have been included in the WWF Global 2000 Project as the Ecoregion ER-45, and have been defined as one of the WWF/IUCN Neotropical Plant Diversity centres (Pantepui or SA-2), considered crucial for the evolution of the Guayanan and the Amazon biota
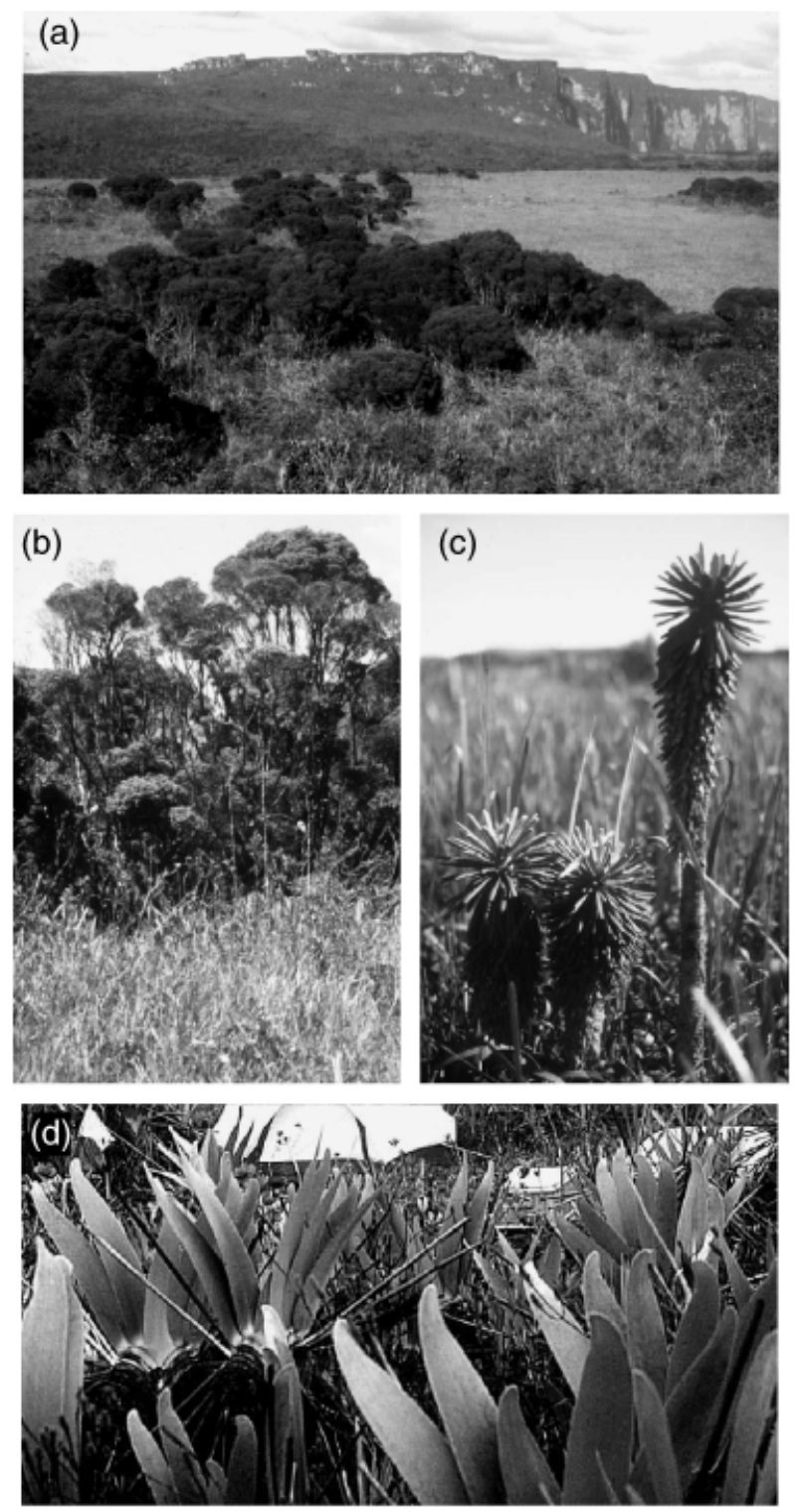

Fig. 2 Vegetation types and significant taxa mentioned in the text. (a) Summit view of the Akopán-tepui, in the Chimantá massif, showing the typical Bonnetia forests (in this case a gallery forest), surrounded by Stegolepis meadows. The cliffs of the higher Churí-tepui are at the background. (b) Closer view of a Bonnetia forest. (c) Specimens of Chimantaea mirabilis (Asteraceae) from the Amurí-tepui, in the Chimantá massif. (d) Stegolepis ligulata from the summit of the Akopán-tepui, in the Chimantá massif (photos V. Rull).

(WWF, IUCN, 1997; Olsson et al., 2000). At present, more than $70 \%$ of the Guayanan territory is under official protection through the existence of seven national parks, five natural monuments, two biosphere reserves, four forest reserves, and one world heritage area (Berry et al., 1995). Nevertheless, the potential 
consequences of future global change have not been fully realized so far. Only a general assessment about an assumed global warming driven decrease in available moisture, and its potential consequences, has been advanced for the Guayana region as a whole (Berry et al., 1995), but the potential effects of the global warming on the summit GH biota have not been addressed to date.

\section{Natural vs. global-warming trends and rates of change}

Until recently, the GH had been considered fairly stable from an environmental point of view. Recent palaeoecological studies, however, have recorded vertical displacements of summit taxa in response to temperature shifts (Rull, 2004a). The estimated extent of these displacements is of a few hundreds of meters for the Holocene (the last $\sim 11500$ years), and of more than $1000 \mathrm{~m}$ for the last glacial epoch. Indeed, during the Last Glacial Maximum (occurred around 21000 years before present), when average temperatures were around $5-6{ }^{\circ} \mathrm{C}$ below the present ones, the neotropical biomes have been estimated to be about $1100 \mathrm{~m}$ below their present altitude (Farrera et al., 1999; Rull, 2004b, c). The subsequent postglacial warming pushed the biota upward again until the present-day situation. Therefore, this upward biotic shift occurred at an average rate of $5.25 \mathrm{~m}$ per century, accompanying a temperature increase of about $0.025^{\circ} \mathrm{C}$ per century. These can be considered the natural (i.e. free from human disturbance) rates of change to which $\mathrm{GH}$ organisms are adapted. A significant acceleration of this warming rate has been observed during the last 250 years, when average temperatures have increased $0.6^{\circ} \mathrm{C}$, which roughly represents a 10 -fold increase $\left(0.24^{\circ} \mathrm{C}\right.$ per century). The IPCC predicted increase for the end of this century (AD 2100) is expected to occur at even higher rates of $1.5-5.8^{\circ} \mathrm{C}$ per century (Houghton et al., 2001). For IPCC prediction purposes, the GH lie in the socalled 'Amazonia' (AMZ) region, for which the projected warming for the end of the present century is of $2-4{ }^{\circ} \mathrm{C}$, depending on the forecasting model and the scenario considered (Houghton et al., 2001). This represents a rate 80-160 times higher than the 'normal' for the GH taxa. Using the present-day lapse rate of about $-0.6^{\circ} \mathrm{C}$ per $100 \mathrm{~m}$ altitude (Berry et al., 1995), an upward shift of environmental conditions between $\sim 330$ and $670 \mathrm{~m}$ is expected for AD 2100. Therefore, many taxa adapted to the highermost parts would be in danger of habitat loss and irreversible extinction. Species with lower and/or wider altitudinal ranges might theoretically survive, but they could hardly follow the estimated rates of change.

\section{Habitat loss estimation and potential extinction}

With the limited data available so far about the GH biota, is not possible to know the exact amount of potential extinction under global warming conditions, but some illustrative estimations are possible. For example, a simple altitudinal range displacement (ARD) analysis shows that about one-third of the endemic genera, all monotypic, are endangered assuming a $2-4{ }^{\circ} \mathrm{C}$ warming (Table 1). Furthermore, several species from polytypic genera that are not under risk as a whole, are also endangered (Table 2). In summary, of the 45 species corresponding to Pantepui endemic genera, $16(\sim 35 \%)$ are threatened of habitat loss by global warming. A similar analysis on all the species of the GH is required for a definite extinction risk assessment, but this is prevented by the lack of detailed phytogeographical information. Because of their remoteness and access difficulties, not all the tepuis have been visited by scientists, and the level of exploration of those surveyed is very little to moderate (Berry et al., 1995). Therefore, the knowledge of the spatial distribution and topographical arrangement of their taxa is far from being enough for a satisfactory risk assessment. However, some characteristic Pantepui taxa, such as, the formerly mentioned Chimantaea, Stegolepis or Bonnetia, are relatively well known and suitable for a first appraisal (Huber, 1988, 1992; Givnish et al., 2000).

The case of Chimantaea is especially significant in the present context because of its narrow geographical range and its preference for highermost summits. Chimantaea has nine described species with two subspecies, all of them restricted to the Chimantá massif and three adjacent tepuis (Auyán, Aprada and Murisipán) (Huber, 1992). As mentioned, they live in the uppermost parts, with a lowermost distribution limit (LDL) around $1900 \mathrm{~m}$, except for two, C. lanocaulis and C. rupicola (Table 2). The maximum altitude of the tepui summits in which Chimantaea occurs is around $2650 \mathrm{~m}$ (Huber, 1992), some $750 \mathrm{~m}$ above the LDL of most of its species. Therefore, using the present-day lapse rate, ARD analysis predicts that all the Chimantaea species would be under risk of habitat loss by a warming of $4.5^{\circ} \mathrm{C}$, which is very close to the maximum predicted. The estimated temperature increases for C. lanocaulis and C. rupicola to loose its altitudinal habitat fall within the risk region (Table 2). Therefore, these two species are in high risk of habitat loss while the others, although less endangered, might be pushed up to small uppermost summit areas, with the consequent habitat reduction and fragmentation. For example, an intermediate increase of $3{ }^{\circ} \mathrm{C}$, would remove the habitat of $C$. lanocaulis and C. rupicola, and restrict the remaining species to altitudes above $2400 \mathrm{~m}$, which are attained only on reduced, 
Table 1 Altitudinal range displacement (ARD) analysis for the endemic genera of the Guayana Highlands in relation to the risk of habitat loss by upward displacement of environmental conditions

\begin{tabular}{|c|c|c|c|c|c|c|}
\hline Genus & Family & LDL & $\mathrm{HPH}$ & UDHL & THL & Species \\
\hline Saccifolium & Saccifoliaceae & 2700 & 3014 & 314 & 1.9 & 1 \\
\hline Marahuacea & Rapateaceae & 2400 & 2800 & 400 & 2.4 & 1 \\
\hline Comoliopsis & Melastomataceae & 2300 & 3014 & 714 & 4.3 & 1 \\
\hline Tyleropappus & Asteraceae & 2200 & 2358 & 158 & 0.9 & 1 \\
\hline Neblinantha & Gentianaceae & 2200 & 3014 & 814 & 4.9 & 2 \\
\hline Huberopappus & Asteraceae & 2000 & 2400 & 400 & 2.4 & 1 \\
\hline Mallophyton & Melastomataceae & 2000 & 2650 & 650 & 3.9 & 1 \\
\hline Coccochondra & Rubiaceae & 2000 & 2400 & 400 & 2.4 & 1 \\
\hline Achnopogon & Asteraceae & 1800 & 2650 & 850 & 5.2 & 2 \\
\hline Pyrrorhiza & Haemodoraceae & 1800 & 3014 & 1214 & 7.3 & 1 \\
\hline Coryphothamnus & Rubiaceae & 1700 & 2450 & 750 & 4.5 & 1 \\
\hline Achlyphilla & Xyridaceae & 1700 & 3014 & 1314 & 7.9 & 1 \\
\hline Chimantaea & Asteraceae & 1600 & 2650 & 1050 & 6.3 & 9 \\
\hline Glossarion & Asteraceae & 1600 & 3014 & 1414 & 8.5 & 2 \\
\hline Quelchia & Asteraceae & 1600 & 2650 & 1050 & 6.3 & 4 \\
\hline Rutaneblina & Rutaceae & 1600 & 3014 & 1414 & 8.5 & 1 \\
\hline Brewcaria & Bromeliaceae & 1500 & 2800 & 1300 & 7.8 & 2 \\
\hline Tepuia & Ericaceae & 1500 & 2650 & 1150 & 6.9 & 7 \\
\hline Celiantha & Gentianaceae & 1500 & 3014 & 1514 & 9.1 & 3 \\
\hline Adenarake & Ochnaceae & 1500 & 3014 & 1514 & 9.1 & 1 \\
\hline Aracamunia & Orchidaceae & 1500 & 1600 & 100 & 0.6 & 1 \\
\hline Adenanthe & Ochnaceae & 1300 & 2650 & 1350 & 8.1 & 1 \\
\hline
\end{tabular}

LDL, lower distribution limit of the genus; $\mathrm{HPH}$, highest potential habitat represented by the highest tepui summit within the present geographical range of the genus; UDHL, upward displacement required for total habitat loss (HPH-LDL); THL, temperature required for total habitat loss (as derived from UDHL, using the present-day lapse rate of $-0.6^{\circ} \mathrm{C} 100 / \mathrm{m}$ ). Altitudes in metres above sea level. Genera threatened of total habitat loss are in bold. The endemic genus Ochthephilus (Melastomataceae) has not been included because of the lack of appropriate data. Raw data from Berry et al. (1995).

Table 2 Altitudinal range displacement (ARD) analysis for the endangered species of polytypic endemic genera of Table 1

\begin{tabular}{lllll}
\hline Species & LDL & HPH & UDHL & THL \\
\hline Achnopogon steyermarkii & 1800 & 2450 & 650 & 3.9 \\
Chimantaea lanocaulis & 2300 & 2650 & 350 & 2.1 \\
C. rupicola & 2100 & 2650 & 550 & 3.3 \\
Glossarion bilabiatum & 2600 & 3014 & 414 & 2.5 \\
Quelchia conferta & 2200 & 2723 & 523 & 3.1 \\
Q. eriocaulis & 2100 & 2650 & 550 & 3.3 \\
Brewcaria marahuacae & 2500 & 2800 & 300 & 1.8 \\
Tepuia vareschii & 2300 & 2450 & 150 & 0.9 \\
T. intermedia & 1800 & 2450 & 650 & 3.9 \\
\hline
\end{tabular}

See Table 1 for codes and details. Raw data from Steyermark et al. $(1997,1998,1999)$.

disjunct areas from the north of the massif (Huber, 1992). In such a situation, besides habitat loss, intense competition for space and resources between the seven eventually surviving Chimantaea species is expected to be an important additional extinction factor.
Bonnetia and Stegolepis are more diversified and widely distributed, both geographically and topographically. Bonnetia is represented in Guayana by 26 species, of which 24 are part of the GH flora and 14 are restricted to it (Huber, 1988). ARD analysis shows that half of Bonnetia species living on the tepui summits, almost all local endemics, are under risk of habitat loss (Table 3). Among these threatened species, one of the most conspicuous elements is B. wurdackii one of the dominants of Bonnetia forests, which taxonomic composition might be significantly affected in this way. In addition, the projected warming would threaten the own existence of the uppermost belt of these forests, situated above $2000 \mathrm{~m}$ (Berry et al., 1995), because the uppermost habitat available is only $600 \mathrm{~m}$ upslope, attainable with a warming of $\sim 3.6^{\circ} \mathrm{C}$, which is within the predicted range. Concerning Stegolepis, 25 of the 28 Guayanan species occur on the $\mathrm{GH}$, and 15 are restricted to these summits, most of them to one single tepui (Huber, 1988). In this case, only 4 species are threatened of ARD habitat loss, but a similar amount is very close to the threshold (Table 4), as in the case of 
Table 3 Altitudinal range displacement (ARD) analysis for Bonnetia species in relation to the risk of habitat loss by upward displacement of environmental conditions

\begin{tabular}{lrrrrr}
\hline Species & LDL & HPH & UDHL & THL & LE \\
\hline Bonnetia bolivarensis* & $\mathbf{2 4 0 0}$ & $\mathbf{2 4 0 0}$ & $\mathbf{0}$ & $\mathbf{0 . 0}$ & + \\
B. wurdackii & $\mathbf{2 1 0 0}$ & $\mathbf{2 6 5 0}$ & $\mathbf{5 5 0}$ & $\mathbf{3 . 3}$ & + \\
B. chimantensis & $\mathbf{2 0 9 0}$ & $\mathbf{2 6 5 0}$ & $\mathbf{5 6 0}$ & $\mathbf{3 . 4}$ & \\
B. toronoensis & $\mathbf{2 0 3 0}$ & $\mathbf{2 6 5 0}$ & $\mathbf{6 2 0}$ & $\mathbf{3 . 7}$ & + \\
B. roseifolia & $\mathbf{1 9 2 2}$ & $\mathbf{2 2 5 0}$ & $\mathbf{3 2 8}$ & $\mathbf{2 . 0}$ & + \\
B. roraimae & 1900 & 2723 & 823 & 4.9 & \\
B. huberiana & 1850 & 2650 & 800 & 4.8 & + \\
B. maguireorum & 1800 & 3014 & 1214 & 7.3 & + \\
B. celiae & $\mathbf{1 8 0 0}$ & $\mathbf{2 4 0 0}$ & $\mathbf{6 0 0}$ & $\mathbf{3 . 6}$ & + \\
B. tepuiensis ssp. minor & 1800 & 2650 & 850 & 5.1 & + \\
B. duidae & $\mathbf{1 7 0 0}$ & $\mathbf{2 3 5 8}$ & $\mathbf{6 5 8}$ & $\mathbf{3 . 9}$ & + \\
B. neblinae & 1700 & 3014 & 1314 & 7.9 & + \\
B. multinervia & 1650 & 2700 & 1050 & 6.3 & \\
B. steyermarkii & 1600 & 2450 & 850 & 5.1 & \\
\hline
\end{tabular}

See Table 1 for codes and details. LE, local endemics. Raw data from Huber (1988).

* Represented by one single locality at the top of Ptari-tepui.

Table 4 Altitudinal range displacement (ARD) analysis for Stegolepis species in relation to the risk of habitat loss by upward displacement of environmental conditions

\begin{tabular}{lrrrrr}
\hline Species & LDL & HPH & UDHL & THL & LE \\
\hline Stegolepis terramarensis & $\mathbf{2 6 0 0}$ & $\mathbf{2 8 0 0}$ & $\mathbf{2 0 0}$ & $\mathbf{1 . 2}$ & + \\
S. maguireana & 1950 & 2650 & 700 & 4.2 & + \\
S. vivipara & 1925 & 2650 & 725 & 4.4 & + \\
S. grandis ssp. jauaensis & $\mathbf{1 9 0 0}$ & $\mathbf{2 2 5 0}$ & $\mathbf{3 5 0}$ & $\mathbf{2 . 1}$ & + \\
S. ligulata & 1850 & 2650 & 800 & 4.8 & + \\
S. pauciflora & $\mathbf{1 8 2 0}$ & $\mathbf{2 3 5 8}$ & $\mathbf{5 3 8}$ & $\mathbf{3 . 2}$ & + \\
S. jauaensis & $\mathbf{1 8 0 0}$ & $\mathbf{2 2 5 0}$ & $\mathbf{4 5 0}$ & $\mathbf{2 . 7}$ & + \\
S. neblinensis & 1700 & 3014 & 1314 & 7.9 & + \\
S. parvipetala ssp. chimantensis & 1660 & 2650 & 990 & 5.9 & \\
S. wurdackii ssp. wurdackii & 1600 & 3014 & 1414 & 8.5 & + \\
S. gleasoniana & 1520 & 2358 & 838 & 5.0 & + \\
S. cardonae & 1500 & 2650 & 1150 & 6.9 & \\
S. hitchcockii ssp. hitchcockii & 1500 & 2200 & 700 & 4.2 & + \\
S. grandis ssp. phelpsiae & 1500 & 2200 & 700 & 4.2 & + \\
S. membranaceae & 1500 & 2800 & 1300 & 7.8 & \\
\hline
\end{tabular}

See Table 1 for codes and details. LE, local endemics. Raw data from Huber (1988).

Chimantaea. All these species are local endemics. S. terramarensis dominates the upper meadows of one single tepui, the Marahuaka (Berry et al., 1995); hence, its disappearance would determine the indirect extinction of other ecologically related taxa. A similar situation is found for S. squarrosa, which is not part of the present analysis because it is not strictly a GH species, but is equally endangered of habitat loss. This species occurs

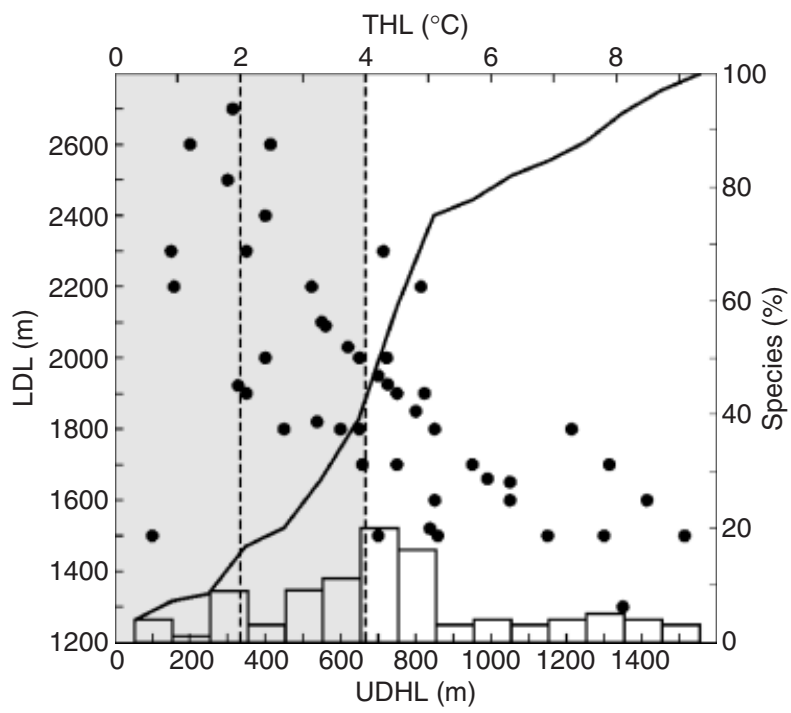

Fig. 3 Graphical altitudinal range displacement (ARD) analysis for all the species analysed. Acronyms as in Table 1. Black dots are the species' arrangement according to their upward displacement required for total habitat loss (UDHL) temperature required for total habitat loss(THL) and lower distribution limit of the genus (LDL) values. Solid line represents the cumulative habitat loss in percentage, and empty bars are the rate of change of this parameter. Broken lines indicate the range of the IPCCpredicted temperature increase for the end of the present century, and the risk region is in grey. Bonnetia bolivarensis has been excluded from the analysis (see Table 3).

between 1200 and $1600 \mathrm{~m}$ altitude, as the absolute dominate of the extensive meadows of the Guaiquinima massif (Rull, 2005a), one of the largest Guayanan table mountains, with more than $1000 \mathrm{~km}^{2}$ of summit area (Steyermark \& Dunsterville, 1980). Because the maximum altitude of this massif is of about $1600 \mathrm{~m}$ (Berry et al., 1995), an upward shift of $400 \mathrm{~m}$, equivalent to a warming of $2.4{ }^{\circ} \mathrm{C}$, would be enough for S. squarrosa to entirely loose its habitat.

The results of gross ARD analysis for the endemic species considered here are summarized graphically for a better general risk appraisal and prediction (Fig. 3). Overall, seven to 27 of the 76 species considered $(\sim 9$ $35 \%)$ are in danger of habitat loss by a predicted warming of $2-4{ }^{\circ} \mathrm{C}$. All of them are GH endemics, so they are at risk of worldwide extinction. However, the ARD framework of Fig. 3 should not be viewed as static. Indeed, IPCC predictions are periodically revised, and continued botanical fieldwork eventually enhances the known range for certain involved species. If so, only temperature thresholds and selected LDLs should be modified to obtain the new prediction framework. In this way it is possible, for example, to evaluate the expected habitat loss under a progressive warming trend. For the species studied here, habitat loss is 
expected to be null below $\sim 1{ }^{\circ} \mathrm{C}$ warming, with a first slight increase between $1^{\circ} \mathrm{C}$ and $2^{\circ} \mathrm{C}$, followed by a drop just after this value, and a subsequent increase between $3{ }^{\circ} \mathrm{C}$ and $4{ }^{\circ} \mathrm{C}$ (Fig. 3). The maximum rates of habitat loss occur around $4-5^{\circ} \mathrm{C}$, which is beyond the maximum warming predicted for the AMZ region by AD 2100 (Houghton et al., 2001). Such a warming, which is very unlikely and would involve altitudinal displacements up to $\sim 1000 \mathrm{~m}$, would remove the habitat of $>70 \%$ of the GH species studied. Beyond $5^{\circ} \mathrm{C}$, rates of habitat loss show a conspicuous drop, because most species have been already affected previously. From these estimations, the high vulnerability of the endemic vascular flora and, by extension, the biota of the GH is manifest and surprising. Furthermore, ARD calculations involve only total habitat loss, and an unknown amount of potential extinction because of habitat reduction below critical size and/or fragmentation should be added.

From a biogeographical/evolutionary point of view, it is interesting that a displacement similar to that recorded since the Last Glacial Maximum to the present because of natural causes $(>1000 \mathrm{~m})$, would cause a biodiversity loss of around $80 \%$ of the endemic species considered here. This agrees with the still untested hypothesis about the existence of unknown enigmatic communities lacking modern analogues on the summits of the tepuis during the last glaciation, and their postglacial extinction (Rull, 2005b). A similar situation has been widely recognized in northern temperate areas but, whereas in them the major source of dissimilarity between past and modern communities rely upon differences in the geographical array and the relative abundance of taxa (Jackson \& Williams, 2004), in the $\mathrm{GH}$, the occurrence of a significant amount of species with no extant representatives has been suggested (Rull, 2005b). The existence of these assumed unknown glacial communities at the top of the tepuis, and the consequent interglacial extinction, would be also extended to past glacial cycles. Since the beginning of late-Cenozoic glaciation of the Northern Hemisphere, about 2.5 million years ago, roughly 40 cycles of glacial extent have occurred (Raymo, 1994), hence, the cumulative extinction of GH taxa since then would have been remarkable. Such extinctions are most probably irreversible because of the lack of source areas, i.e. terrains higher than $3000 \mathrm{~m}$ altitude, able to preserve populations and provide propagules for recolonization (Rull, 2005b). The present-day, global-warming scenario is analogous to a typical postglacial warming trend, the difference being a matter of rate of change. Indeed, the extinction magnitude is expected to be similar, but it will occur in a century instead of $\sim 20000$ years.

It should be stressed that ARD results do not necessarily involve straightforward extinction. They are arguments for both lower and higher extinction amounts than expected from ARD analysis alone. For example, some studies show that temperate high-mountain species migrate upwards at lower rates than predicted using solely lapse rate estimations (Grabherr et al., 1994), thus, reducing their effective risk of habitat loss and extinction. On the other hand, not only habitat loss, but also critical habitat size and fragmentation, are important extinction-risk factors for mountain taxa (Dinrböck et al., 2003). In this way the excessive habitat reduction may lead to the existence of small and isolated populations, insufficient to guarantee the continuity of the involved species (Clubbe, 1996). In the tepui summits, given its characteristic stepped topography, it is expected that habitat reduction by upward displacement will be even more drastic than in other mountains with a more conical shape. In addition, the extinction of a keystone species, that which is critical for the existence of a community (Heywood \& Iriondo, 2003), can have a magnifying effect. This would be the case for the paramoid-forming Chimantaea species and those of Bonnetia and Stegolepis that dominate the forests and meadows, respectively. Indeed, their extinction would promote the disappearance of other species not directly threatened by environmental change, but highly dependent on the existence of these communities. Another element that can enhance extinction is the successful establishment of introduced and/or invasive species (Clubbe, 1996), which in this case would arrive from lower altitudes pushed up by the warming trend. Therefore, profound changes are expected to occur in the composition of GH uppermost communities under climate forcing, as it has been recorded in the past (Bush, 2002).

\section{Future studies, final remarks and some conservation insights}

Although the results of the present study should be considered preliminary and their extrapolation still premature, the numbers are striking and stress the importance of a more detailed study on the potential consequences of the predicted global warming in the Pantepui region. Such study should be based on detailed field observations using satellite-positioning systems, and high-resolution techniques of spatial/ topographical data analysis such as GIS tools. Fortunately, the tepuian localities studied so far are relatively well documented (Berry et al., 1995), and some of these measures are still possible, but an extensive research program including new field surveys oriented towards specific objectives within the climate change framework is needed. A useful complementary tool would be the extrapolation of observed upward migration rates in recent times, namely the last century, a method 
successfully used in other mountains (Grabherr et al., 1994; Dinrböck et al., 2003). In the GH, in spite of the long history of their exploration (Berry et al., 1995), these historical records seem, at first sight, insufficient, but a more careful consideration of this possibility is needed. A better basic phytogeographical knowledge using these advanced techniques would allow substitution of simple ARD analysis by more sophisticated prediction tools, for example, spatially constrained models able to simulate the expected distribution area of any species at any possible future warming scenario (e.g. Halloy \& Mark, 2003). This would enable more realistic and accurate predictions, given the complex GH topography and environmental variability. Finally, not only temperature shifts, but also changes in available moisture are known to be important climatic forcings for living communities, especially in the tropics. However, the IPCC-projected precipitation change for the $\mathrm{AMZ}$ region by $\mathrm{AD} 2100$ is roughly $-5 \%$ to $5 \%$ with respect to the present (Houghton et al., 2001), which is negligible as compared with temperature change.

The global warming scenario suggested for this study is surprising, given the present healthy and apparently safe aspect of the GH biomes. This is especially true if the comparison is made with the climatically stressed high-mountain environments immediately below the snowline of the highest mountain ranges. Uppermost taxa from highermost mountain ranges might have the possibility to accommodate future warming by colonizing higher altitudes presently under permanent snow because of increased, warming-induced, snow ablation. For example, it is estimated that $50-90 \%$ of the European alpine glaciers will be melted by the end of the century (Watson \& Haeberli, 2004). Furthermore, northward migration would be also theoretically possible in those mountain ranges with latitudinal continuity. In the $\mathrm{GH}$, both latitudinal and altitudinal migration ways are hindered by physical isolation and the absence of a nival stage, thus habitat loss and potential extinction seems unavoidable and irreversible for many atop taxa. Therefore, future climate change is expected to reverse the present-day stress conditions on mountaintop biotas, so 'the last shall be the first, and the first last'. Given the large amount of endemism in the $\mathrm{GH}$, the projected extinction directly hits global biodiversity, a situation that is not expected for mountains of lower endemicity levels as, for example, many temperate ranges. In addition, the potential for future biodiversity generation in the Guayana and neighbouring regions would be also compromised, because the $\mathrm{GH}$ have been considered as neotropical 'diversity pumps', because of their salient role in biotic diversification processes (Rull, 2005b).

The case of the GH is an issue of global concern. Many other mountain top biotas with characteristics similar to the GH (high endemism, geographical isolation, absence of a nival stage) exist elsewhere, especially on tropical and subtropical islands, and in the Mediterranean and circum-Mediterranean region. They should be urgently considered for conservation policies if the warming-driven global biodiversity loss has to be mitigated. Strategies for the preservation of these menaced biotas are challenging, as in situ policies (Heywood \& Iriondo, 2003) are difficult to undertake. One possibility is to declare these areas as biodiversity 'hotspots' (Myers et al., 2000) in relation to global warming, which would help delineating temporary and local protection actions. This proposal is supported by studies of worldwide bird diversity patterns (Orme et al., 2005). Emphasis should be placed on conservation of individual taxa rather than communities. Palaeoecological studies support the view of communities as transient states of species' aggregation, which repeatedly form and vanish because of differential individualistic responses of their components to environmental forcing, a situation that is expected to be true also in the future (Bush, 2002). However, effective environmental protection to prevent habitat loss seems unattainable under continued global warming. Alternatively, some ex situ strategies could be considered. They should be based on a combined ecological and palaeoecological surveys oriented to: (1) identify all the potentially vulnerable species, (2) accurately estimate and compare the magnitude and rates of their upward migration under natural and global warming conditions, (3) assess the extinction risk for each species and (4) define conservation priorities accordingly. With this information, several ex situ actions to preserve genetic material (botanical gardening, seed/pollen/gene/DNA storing, etc.) might be evaluated. It would be asked if it is ethical to preserve such taxa considering the low probability of a short/medium-term environmental recovery needed to eventually reintroduce them under natural conditions. A reasonable answer to this question seems to be that preservation is the only way of keeping this possibility alive, while leaving endangered taxa to extinction means to make a decision of irreversible consequences.

\section{Acknowledgements}

This study is part of the project PANTEPUI (http://einstein.uab.es/vrull/pantepui/main.htm), which is funded by the Spanish BBVA Foundation. The authors are grateful to the referees for remarks and constructive discussion on several aspects of the manuscript.

\section{References}

Berry PE, Holst BK, Yatskievych K (1995) Flora of the Venezuelan Guayana. Vol. 1, Introduction. Missouri Botanical Garden Press, St Louis. 
Briceño HO, Schubert C (1990) Geomorphology of the Gran Sabana, Guayana Shield, Southeastern Venezuela. Geomorpholohy, 3, 125-141.

Bush MB (2002) Distributional change and conservation on the Andean flank, a palaeoecological perspective. Global Ecology and Biogeography, 11, 463-473.

Chapin FS, Callaghan TV, Bergeron Y et al. (2004) Global change and the boreal forest: thresholds, shifting states or gradual change? Ambio, 33, 361-365.

Clubbe C (1996) Threats to biodiversity. In: Global Environmental Issues (eds Blackmore R, Reddish A), Hodder \& Stoughton, London.

Dirnböck T, Dullinger S, Grabherr G (2003) A regional impact assessment of climate and land-use change on apline vegetation. Journal of Biogeography, 30, 401-417.

Dullinger S, Dirnböck T, Grabher G (2003) Patterns of shrub invasion into high mountain grasslands of the northern calcareous Alps, Austria. Arctic, Antarctic and Alpine Research, 35, 434-441.

Farrera I, Harrison SP, Prentice IC et al. (1999) Tropical climates at the last glacial maximum: a new synthesis of terrestrial paleoclimate data. I. Vegetation, lake-levels and geochemistry. Climate Dynamics, 15, 823-856.

Givnish TJ, Evans TM, Zjhra ML et al. (2000) Molecular evolution, adaptative radiation, and geographic diversification in the amphiatlantic family Rapateaceae: evidence from $n d h F$ sequences and morphology. Evolution, 54, 1915-1937.

Grabherr G, Gottfried M, Pauli H (1994) Climate effects on mountain plants. Nature, 369, 448.

Halloy SRP, Mark AF (2003) Climate-change effects on alpine plant biodiversity: a New Zealand perspective on quantifying the threat. Arctic, Antarctic and Alpine Research, 35, 248-254.

Heywood VH, Iriondo JM (2003) Plant conservation: old problems, new perspectives. Biological Conservation, 113, 321-335.

Houghton JT, Ding Y, Griggs DJ et al. (2001) Climate Change 2001: The Scientific Basis. Cambridge University Press, Cambridge.

Huber O (1988) Guayana highlands versus Guayana lowlands: a reappraisal. Taxon, 37, 595-614.

Huber O (1992) El Macizo Del Chimantá. Un Ensayo Ecológico Tepuyano. Oscar Todtmann, Caracas.

Huber O (1994) Recent advances in the phytogeography of the Guayana region, South America. Mémoires de la Société Biogéographique (3ème série), 4, 53-63.

Jackson ST, Williams JW (2004) Modern analogs in Quaternary paleoecology: here today, gone yesterday, gone tomorrow? Annual Reviews of Earth and Planetary Sciences, 32, 495-537.

Keller F, Kienast F, Beniston M (2000) Evidence of response of vegetation to environmental change on high-elevation sites in the Swiss Alps. Regional Environmental Change, 1, 70-77.

Körner C (2004) Mountain biodiversity, its causes and function. Ambio Special Report, 13, 11-17.

Luteyn JL (1999) Páramos. A Checklist of Plant Diversity, Geographical Distribution, and Botanical Literature. The New York Botanical Garden Press, New York.

Maguire B (1970) On the flora of the Guayana Highland. Biotropica, 2, 85-100.

McCarthy JJ, Canziani OF, Leary NA et al. (2001) Climate Change 2001: Impacts, Adaptation, and Vulnerability. Cambridge University Press, Cambridge.
Molau U (2004) Mountain biodiversity patterns at low and high latitudes. Ambio Special Report, 13, 24-28.

Myers N, Mittermeier RA, da Fonseca GAB et al. (2000) Biodiversity hotspots for conservation priorities. Nature, 403, 853-858.

Olsson DM, Dinerstein E, Abell R et al. (2000) The Global 2000, A Representation Approach to Conserving Earth's Distinctive Ecoregions. World Wildlife Fund, Washington.

Orme CD, Davies RG, Burgess M et al. (2005) Clobal hotspots of species richness are not congruent with endemism or threat. Nature, 436, 1016-1019.

Parmesan C, Yohe G (2003) A globally coherent fingerprint of climate change impacts across natural systems. Nature, 421, 37-42.

Pauli H, Gottfreid M, Graebherr G (1996) Effects of climate change on mountain ecosystems-upward shiting of alpine plants. World Resource Reviews, 8, 382-390.

Raymo ME (1994) The initiation of Northern Hemisphere glaciation. Annual Reviews of Earth and Planeatry Sciences, 22, 353-383.

Root TL, Price JT, Hal KR et al. (2003) Fingerprints of global warming on wild animals and plants. Nature, 421, 57-60.

Rull V (2004a) An evaluation of the Lost World and vertical displacement hypotheses in the Chimantá massif, Venezuelan Guayana. Global Ecology and Biogeography, 13, 141-148.

Rull V (2004b) Is the 'Lost World' really lost? Palaeoecological insights into the origin of the peculiar flora of the Guayana Highlands. Naturwissenschaften, 91, 139-142.

Rull V (2004c) Biogeography of the 'Lost World', a palaeoecological perspective. Earth-Science Reviews, 67, 125-137.

Rull V (2005a) Palaeovegetational and palaeoenvironmental trends in the summit of the Guaiquinima massif (Venezuelan Guayana) during the Holocene. Journal of Quaternary Science, 20, 135-145.

Rull V (2005b) Biotic diversification in the Guayana Highlands: a proposal. Journal of Biogeography, 32, 921-927.

Steyermark JA (1979) Plant refuge and dispersal centres in Venezuela: their relict and endemic element. In: Tropical Botany (eds Larsen K, Holm-Nielsen L), Academic Press, New York.

Steyermark JA (1986) Speciation and endemism in the flora of the Venezuelan tepuis. In: High Altitude Tropical Biogeography (eds Vuilleumier F, Monasterio M), Oxford University Press, New York.

Steyermark JA, Berry PE, Holst BK et al. (1997) Flora of the Venezuelan Guayana. Vol. 3, Araliaceae-Cactaceae. Missouri Botanical Garden Press, St Louis.

Steyermark JA, Berry PE, Holst BK et al. (1998) Flora of the Venezuelan Guayana. Vol. 4, Caesalpiniaceae-Ericaceae. Missouri Botanical Garden Press, St Louis.

Steyermark JA, Berry PE, Holst BK et al. (1999) Flora of the Venezuelan Guayana. Vol. 3, Eriocaulaceae-Lentibulariaceae. Missouri Botanical Garden Press, St Louis.

Steyermark JA, Dunsterville GCK (1980) The lowland floral element on the summit of Cerro Guaquinima and other cerros of the Guayana highland of Venezuela. Journal of Biogeography, 7, 285-303.

Watson RT, Haeberli W (2004) Environmental threats, mitigation strategies and high-mountain areas. Ambio Special Report, 13, $2-10$.

WWF, IUCN (1997) Centres of Plant Diversity, a Guide and Strategy for their Conservation, Vol. 3. The Americas. IUCN Publication Unit, Cambridge. 